\title{
Pentingnya Pendidikan Karakter Di Masa Pandemi Covid 19
}

\section{Dwi Suparwati}

\author{
SD Islam Al Furqan \\ dwisuparwati02@gmail.com
}

\section{Article History \\ received 3/12/2020}

revised 17/12/2020

\begin{abstract}
Character education is very important in order to shape the character of the nation. Character education can make students become social beings who help each other, are civilized and polite. Teaching and learning activities carried out in Indonesia previously were face-to-face or offline learning. At the time of face-to-face or offline learning, teachers can easily observe the character of students and can provide direction and character education easily. However, the COVID-19 pandemic has forced the change of face-to-face or offline learning to be replaced by online or virtual. For this reason, collaboration and communication between teachers and parents of students to jointly apply character education is very necessary. Teachers can provide good habituation tasks, by implementing PPK (Strengthening Character Education) in online or virtual activities, and parents working with teachers to supervise student activities from home.
\end{abstract}

Keywords: character, character education, the COVID-19 pandemic period

\begin{abstract}
Abstrak
Pendidikan karakter sangat penting dalam rangka membentuk karakter Bangsa. Pendidikan karakter dapat menjadikan peserta didik menjadi makhluk sosial yang saling membantu, beradab dan sopan-santun. Kegiatan belajar mengajar yang dilakukan di Indonesia sebelumnya adalah pembelajaran tatap muka atau offline. Pada saat pembelajaran tatap muka atau offline guru dapat dengan mudah mengamati karakter peserta didik serta dapat memberikan pengarahan dan pendidikan karakter dengan mudah. Namun pandemik COVID-19 memaksa pergantian pembelajaran tatap muka atau offline diganti menjadi online atau virtual. Untuk itu kerjasama dan komunikasi antara guru dan orang tua peserta didik untuk sama-sama menerapkan pendidikan karakter sangat diperlukan. Guru dapat memberikan tugas-tugas pembiasaan baik, dengan menerapkan PPK (Penguatan Pendidikan Karakter) pada kegiatan online atau virtual, dan orang tua bekerjasama dengan guru mengawasi kegiatan peserta didik dari rumah.
\end{abstract}

Kata kunci: karakter, pendidikan karakter, masa pandemic COVID 19

Social, Humanities, and Education Studies (SHEs): Conference Series https://jurnal.uns.ac.id/shes

p-ISSN 2620-9284 e-ISSN 2620-9292 


\section{PENDAHULUAN}

Pendidikan adalah pembelajaran pengetahuan, keterampilan, dan kebiasaan sekelompok orang yang diturunkan dari satu generasi ke generasi berikutnya melalui pengajaran, pelatihan, atau penelitian. Pendidikan di sekolah bukan hanya mempelajari materi pelajaran saja, melainkan penanaman karakter pada peserta didik. Karena tujuan pendidikan bukan hanya mencerdaskan peserta didik, melainkan membuat kepribadian peserta didik lebih baik. Hal tersebut sesui dengan tujuan pendidikan nasional dalam pasal 3 Undang-undang No.20 Tahun 2003 yang berbunyi "Pendidikan nasional berfungsi mengembangkan kemampuan dan membentuk watak serta peradaban bangsa yang bermartabat dalam rangka mencerdaskan kehidupan bangsa, bertujuan untuk berkembangnya potensi peserta didik agar menjadi manusia yang beriman dan bertakwa kepada Tuhan Yang Maha Esa, berakhlak mulia, sehat, berilmu, cakap, kreatif, mandiri, dan menjadi warga negara yang demokratis serta bertanggung jawab"

Menteri Pendidikan dan Kebudayaan Nadiem Makarim dalam program merdeka belajarnya menekankan pendidikan karakter. Hal tersebut dapat dilihat dari pokok kebijakan baru program merdeka belajar, di mana Nadiem menggantikan Ujian Nasional dengan konsep Asesmen Kompetensi Minimum dan Survei Karakter. Karakter atau watak adalah sifat batin yang mempengaruhi segenap pikiran, perilaku, budi pekerti, dan tabiat yang dimiliki manusia atau makhluk hidup lainnya. Pendidikan karakter dapat menjadikan peserta didik menjadi makhluk sosial yang saling membantu, beradab dan sopan-santun. Pendidikan ini sangat berkaitan dengan pendidikan moral, di mana tujuannya yaitu untuk mendidik dan membentuk peserta didik menjadi manusia yang dapat bermanfaat bagi dirinya serta lingkungannya. Pendidikan karakter merupakan bentuk kegiatan manusia yang di dalamnya terdapat suatu tindakan yang mendidik diperuntukkan bagi generasi selanjutnya. Tujuan pendidikan karakter adalah untuk membentuk penyempurnaan diri individu secara terus-menerus dan melatih kemampuan diri demi menuju kearah hidup yang lebih baik. Pendidik dapat menyelipkan nilai religius dan toleransi pada sela-sela pemaparan materi. Selain itu berkaitan dengan dunia pendidikan, pendidikan karakter bertujuan untuk meningkatkan mutu dan hasil pendidikan. Prinsip implementasi pendidikan karakter yaitu pembelajaran dibuat agar peserta didik dapat mengikuti dengan aktif dan menyenangkan. Pembelajaran aktif berpusat pada peserta didik berarti peserta didik berpartisipasi dalam proses belajar sebanyak mungkin.Tenaga pendidik bertugas menuntun peserta didiknya agar aktif tanpa harus mengatakan bahwa ia harus aktif. Pendidik juga perlu merencakaan kegiatan pembelajaran yang dapat menimbulkan peserta didik aktif.

COVID-19 memberikan dampak yang buruk bagi kehidupan manusia. Segala aktivitas menjadi terhambat dan terbatas. Begitu pula di bidang pendidikan. Peserta didik harus belajar dan melakukan aktivitasnya di rumah. Untuk mengatur hal tersebut pemerintah telah dengan tegas mengeluarkan berbagai kebijakan di segala bidang (Suharyanto, 2020). Di bidang kesehatan, pemerintah telah mengeluarkan kebijakan mengenai pembatasan sosial berskala besar (PSBB) dan penerapan perilaku hidup bersih dan sehat (PHBS). Di bidang pendidikan kementerian pendidikan telah mengeluarkan surat edaran mengenai pembelajaran dari rumah (Learning from Home) (Sekretaris Kabinet, 2020). Kegiatan belajar mengajar yang dilakukan di Indonesia sebelumnya adalah pembelajaran tatap muka atau offline. Pada saat pembelajaran tatap muka atau offline guru dapat dengan mudah mengamati karakter peserta didik dan dapat memberikan pengarahan dan pendidikan karakter dengan mudah. Namun pandemik COVID-19 memaksa pergantian pembelajaran tatap muka atau offline diganti menjadi online atau virtual. Pada saat pembelajaran online baik guru dan peserta didik dipermudah dengan sistem pembelajaran via online dimana guru dan peserta didik tidak perlu bertemu untuk mengadakan kegiatan belajar mengajar. 
Sehingga pendidik harus mampu berinovasi membuat pembelajaran daring dengan sekreatif mungkin sehingga nilai-nilai karakter pada peserta didik dapat tetap diimplementasikan.

Artikel ini dengan menggunakan metode kualitatif dan penjelasan yang analisisdeskriptif mencoba mengkaji tentang pentingnya pendidikan karakter dimasa pandemic COVID-19.

Karakter

\section{PEMBAHASAN}

Karakter merupakan watak, tabiat, akhlak, atau kepribadian seseorang yang terbentuk dari hasil internalisasi berbagai kebajikan (virtues) yang diyakini dan digunakan sebagai landasan untuk cara pandang, berpikir, bersikap, dan bertindak. karakter dapat pula dinyatakan sebagai cara berpikir dan berperilaku yang menjadi ciri khas tiap individu untuk hidup dan bekerjasama, baik dalam lingkup keluarga, masyarakat, bangsa dan Negara. Dengan demikian, karakter berkaitan dengankekuatan moral, berkonotasi 'positif', bukan netral. Jadi, 'orang berkarakter' adalah orang yang mempunyai kualitas moral positif. (Mohammad Kosim, 2011:86-92). Karakter nerupakan hal yang hakiki dimiliki oleh setiap orang. Karakter juga menjadi ciri setiap individu yang satu dengan individu yang lainnya (Sudrajat, 2011).

\section{Pengertian Pendidikan Karakter}

Arti pendidikan menuru Ki Hajar Dewantara adalah daya upaya untuk memajukan budi pekerti, pikiran, serta jasmani anak, agar dapat memajukan kesempurnaan hidup yaitu hidup dan menghidupkan anak yang selaras dengan alam dan masyarakat. Pendidikan berlangsung dalam lingkungan keluarga, lingkungan perguruan (sekolah) dan lingkungan masyarakat (Rahmat, 2021:52). Pembelajaran yang terjadi pada anak sebenarnya diperoleh melalui keluarga, dalam dunia pendidikan disebut pendidikan informal. Keluarga merupakan lingkungan awal seorang anak melakukan interkasi, mengalami tumbuh kembang secara fisik dan emosinya (Hulukati, 2015). Kegiatan positif yang dilakukan dirumah secara bersama-sama akan membentuk sebuah ikatan emosional yang baik antara anak dan orang tua. Sebuah chemistry yang akan mucul selama melakukan kegiatan bersama-sama, menumbuhkan cinta yang nantinya menjadi sebuah kebiasaan (habbit) (Ratminingsih, 2019). Dalam keluarga, orang tua mempunyai peran yang sangat penting dalam membentuk dan mengembangkan karakter dan kepribadian anak. Sedangkan dalam lingkungan sekolah pendidikan mempunyai dua tujuan, yang pertama untuk membuat manusia cerdas dan pintar (smart) dan kedua membuat mereka menjadi manusia yang baik (berkarakter). Namun, membuat manusia menjadi cerdas dan pintar bukanlah hal yang sulit. Tetapi sebaliknya, membuat manusia berkarakter jauh lebih sulit, Sehingga masalah moral kerap menjadi persoalan parah yang menghantui kehidupan manusia kapan saja dan dimana saja. Untuk itu pendidikan diharapkan tidak hanya menjadikan insan yang cerdas saja namun juga menjadikan manusia yang berakhlak dan berbudi. Pendidikan karakter merupakan suatu keniscayaan dalam upaya menghadapi berbagai tantangan pergeseran karakter yang dihadapi saat ini, Pendidikan karakter bertujuan mengembangkan kemampuan seseorang untuk memberikan keputusan baik-buruk, melihat apa yang baik, dan mewujudkan kebaikan itu dalam kehidupan sehari-hari dengan sepenuh hati (Koesoma, 2007; Muslich, 2011; dan Zainal, 2011). Pendidikan karakter harus ditumbuhkembangkan sejak dini dan berkelanjutan, mulai dari lingkungan keluarga, sekolah hingga lingkungan masyarakat luas.

Gerakan PPK (Penguatan Pendidikan Karakter), yang dicanangkan oleh Kementrian Pendidikan dan Kebudayaan Republik Indonesia pada tahun 2017, mengidentifikasi lima nilai utama karakter yang saling berkaitan dalam membentuk jejaring nilai yang perlu dikembangkan sebagai prioritas, yaitu: nilai religious, 
nasionalis, mandiri, gotong-royong, dan integritas (Kemendiknas RI, 2010a dan 2010b; Asmani, 2011: dan Komalasari \& Saripudin, 2017). Pertama, nilai karakter religius mencerminkan keberimanan terhadap Tuhan Yang Maha Esa, yang diwujudkan dalam perilaku melaksanakan ajaran agama dan kepercayaan yang dianut, menghargai perbedaan agama, menjunjung tinggi sikap toleran terhadap pelaksanaan ibadah agama dan kepercayaan lain, serta hidup rukun dan damai dengan pemeluk agama lain. Nilai karakter religius ini meliputi tiga dimensi relasi sekaligus, yaitu: hubungan individu dengan Tuhan, individu dengan sesama, dan individu dengan alam semesta atau lingkungan (Asmani, 2011; dan Ningsih, 2015). Nilai karakter religius ini ditunjukkan dalam perilaku mencintai dan menjaga keutuhan ciptaan Tuhan. Sub-nilai religius, antara lain, cinta damai, toleransi, menghargai perbedaan agama dan kepercayaan, teguh pendirian, percaya diri, kerjasama antar pemeluk agama dan kepercayaan, anti-buli dan kekerasan, persahabatan, ketulusan, tidak memaksakan kehendak, mencintai lingkungan, serta melindungi yang kecil dan tersisih (Samani \& Hariyanto, 2011; Zainal, 2011; dan Kusnoto, 2017). Kedua, nilai karakter nasionalis merupakan cara berpikir, bersikap, dan berbuat yang menunjukan kesetiaan, kepedulian, dan penghargaan yang tinggi terhadap bahasa, lingkungan fisik, sosial, budaya, ekonomi, dan politik bangsa, menempatkan kepentingan bangsa dan negara di atas kepentingan diri dan kelompoknya. Sub-nilai nasionalis, antara lain, apresiasi budaya bangsa sendiri, menjaga kekayaan budaya bangsa, rela berkorban, unggul dan berprestasi, cinta tanah air, menjaga lingkungan, taat hukum, disiplin, serta menghormati keragaman budaya, suku, dan agama (Muslich, 2011; Rahardjo, 2013; dan Priyambodo, 2017). Ketiga, nilai karakter mandiri merupakan sikap dan perilaku tidak bergantung pada orang lain dan mempergunakan segala tenaga, pikiran, dan waktu untuk merealisasikan harapan, mimpi, dan cita-cita. Sub-nilai mandiri, antara lain, etos kerja atau kerja keras, tangguh dan tahan banting, daya juang, profesional, kreatif, keberanian, dan menjadi pembelajar sepanjang hayat (Yusuf, 2017). Keempat, nilai karakter gotong-royong mencerminkan tindakan menghargai semangat kerja sama dan bahu membahu menyelesaikan persoalan bersama, menjalin komunikasi dan persahabatan, serta memberi bantuan atau pertolongan pada orang-orang yang membutuhkan. Sub-nilai gotong-royong, antara lain, menghargai, kerja sama, inklusif, komitmen atas keputusan bersama, musyawarah dan mufakat, tolong-menolong, solidaritas, empati, anti diskriminasi, anti kekerasan, dan sikap kerelawanan (Zainal, 2011; dan Wahono \& Priyanto, 2017). Kelima, nilai karakter integritas merupakan nilai yang mendasari perilaku yang didasarkan pada upaya menjadikan dirinya sebagai orang yang selalu dapat dipercaya dalam perkataan, tindakan, dan pekerjaan, serta memiliki komitmen dan kesetiaan pada nilai-nilai kemanusiaan dan moral atau integritas moral. Karakter integritas meliputi sikap tanggung jawab sebagai warga negara, aktif terlibat dalam kehidupan sosial, serta konsistensi dalam tindakan dan perkataan yang berdasarkan kebenaran. Sub-nilai integritas, antara lain, kejujuran, cinta pada kebenaran, setia, komitmen moral, anti korupsi, keadilan, tanggung jawab, keteladanan, dan menghargai martabat individu (Asmani, 2011; Samani \& Hariyanto, 2011; Barnawi \& Arifn, 2012; dan Yusuf, 2017)

\section{Pandemi Covid 19}

Pandemi adalah wabah penyakit yang terjadi secara luas diseluruh dunia. Dengan kata lain, penyakit ini sudah menjadi masalah bersama bagi seluruh warga dunia. Pademic COVID-19 yang sedang terjadi di negeri ini sungguh sangat memprihatinkan, sudah setahun lebih berjalan, kasus penularan virus COVID-19 masih tinggi. COVID-19 merupakan penyakit yang tergolong baru dimana penyebab, asal muasal virus ini belum diketahui secara pasti (Chan dkk, 2020). Begitu berbahayanya penyakit ini, sehingga pemerintah berupaya keras untuk menanggulangi penyebaran COVID-19 ini. Sampai saat ini belum ditemukannya obat serta vaksin untuk masalah 
ini sehingga jalan satu-satunya hanyalah memutus mata rantai penyebaran COVID-19 ini. Cara yang paling ampuh untuk memutus rantai penyebaran wabah ini adalah dengan melakukan pembatasan sosial (sosial distancing) dan pembatasan fisik (physical distancing) (Tim Kerja Kementerian Dalam Negeri, 2020). Selama pandemic COVID-19 menjaga sekaligus memantau kesehatan adalah hal penting yang tidak boleh diabaikan, untuk itu kita selalu dituntut menerapkan protokol kesehatan kapanpun dan dimanapun kita berada salah satunya dengan menghindari segala hal yang berkaitan dengan kerumunan. Berbagai upaya dilakukan pemerintah untuk mencegah penularan COVID-19 diantaranya dengan pembatasan kegiatan sosial, baik kegiatan keagamaan, kemasyarakatan dan juga pendidikan. Dengan demikian kegiatan belajar mengajar yang sebelumnya dilakukan di sekolah harus dilakukan secara daring atau virtual.

\section{SIMPULAN}

Pendidikan karakter sangat penting karena pendidikan bukan hanya sekedar mentransfer pengetahuan akan tetapi juga membentuk karakter peserta didik yang baik. Membuat manusia menjadi cerdas dan pintar bukanlah hal yang sulit, akan tetapi membuat manusia berkarakter baik dan bijak jauh lebih sulit. Maka jangan heran bila masalah moral kerap menjadi persoalan parah yang menghantui kehidupan manusia kapan saja dan dimana saja. Untuk mengatasi hal tersebut peran aktif guru dan orang tua sangat berpengaruh terhadap keberhasilan pendidikan karakter. Pendidik dapat menyelipkan nilai religius dan toleransi pada sela-sela pemaparan materi, selain itu kerjasama dan komunikasi anatara guru dan orang tua peserta didik untuk sama-sama menerapkan pendidikan karakter sangat diperlukan.

Kegiatan belajar mengajar yang dilakukan di Indonesia sebelumnya adalah pembelajaran tatap muka atau offline. Pada saat pembelajaran tatap muka atau offline guru dapat dengan mudah mengamati karakter murid dan dapat memberikan pengarahan dan pendidikan karakter dengan mudah. Namun pandemik covid-19 memaksa pergantian pembelajaran tatap muka atau offline diganti menjadi online atau virtual. Kreatifitas guru dalam melaksanakan kegiatan belajar dengan cara online sangat berpengaruh pada keberhasilan pendidikan, sehingga guru dituntut untuk kreatif dalam pembelajaran baik dalam pengetahuan maupun karakter peserta didik. Pada saat pembelajaran online baik guru dan murid dipermudah dengan sistem pembelajaran via online dimana guru dan murid tidak perlu bertemu untuk mengadakan kegiatan belajar mengajar sehingga guru tidak dapat menerapkan pendidikan karakter secara langsung pada peserta didik. Untuk itu kerja sama antara guru dan orang tua sangat penting untuk menunjang keberhasilan pendidikan. Guru dapat memberikan tugas-tugas pembiasaan baik seperti, (1) Ibadah sesuai dengan agama dan kepercayaannya, (2) Cinta tanah air contohnya dengan membeli dan memakai produk dalam negeri, (3) Melatih kemandirian contohnya dengan mengerjakan tugas-tugas dirumah secara mandiri, (4) Melatih disiplin dalam segala hal, dan (5) Mengedepankan kejujuran dan konsisten, (5) Menghormati orang yang lebih tua, dan orang tua bekererjasama dengan guru mengawasi kegiatan peserta didik dari rumah. Pendidik juga harus mengimplementasikan nilai menghargai prestasi peserta didik dengan memberikan reward berupa pujian atau bahkan barang jika ia mempunyai kelebihan dalam mengikuti pembelajaran daring yang telah berlangsung.

\section{DAFTAR PUSTAKA}

Asmani, Jamal Ma'mur. (2011). Buku Panduan Pendidikan Karakter di Sekolah. Yogyakarta: Diva Press.

Dewantara Ki Hadjar, (1962). Karja Bagian 1; Pendidikan. Jokjakarta: Penerbit MLPTS (Madjelis Luhur Perguruan Taman Peserta didik) 
Chan, J. F., Yuan, S., Koh, K. H., To, K. K., Chu, H., Yang J., ... Yuen, K. Y. (2020). A Familial Cluster of Pneumonia Associated with The 2019 Novel Coronavirus Indicating287 Person-To-Person Transmission: A Study Of Family Cluster. Lancet. 395(10223):514-523. Jurnal Ilmu Pendidikan Vol. 3 No. 2 (2020).

Hulukati, W. (2015). Peran Lingkungan Keluarga terhadap Perkembangan Anak. Jurnal Ilmu Pendidikan Vol. 3 No. 2 (2020).

I Putu Yoga Purandina1, I Made Astra Winaya2. 2020. Pendidikan Karakter di Lingkungan Keluarga Selama Pembelajaran Jarak Jauh pada Masa Pandemi COVID-19. Jurnal IImu Pendidikan Jayapangus Press. Vol. 3 No. 2. Hal 271-290.

Kemendiknas RI [Kementerian Pendidikan Nasional Republik Indonesia]. (2010a). Pendidikan Karakter Terintegrasi dalam Pembelajaran di Sekolah. Jakarta: Direktorat PSMP.

Kemendiknas RI [Kementerian Pendidikan Nasional Republik Indonesia]. (2010b). Pengembangan Pendidikan Budaya dan Karakter; Pedoman untuk Sekolah. Jakarta: Kemendiknas RI.

Komalasari, Kokom \& Didin Saripudin. (2017). Pendidikan Karakter: Konsep dan Aplikasi Living Values Education. Bandung: Refka Aditama.

Komara Endang, (2018). Penguatan Pendidikan Karakter dan Pembelajaran Abad 21. South-East Asian Journal for Youth, Sports \& Health Education, Volume 4(1). Hal 19-26.

Muslich, Masnur. (2011). Pendidikan Karakter: Menjawab Tantangan Krisis Multidimensional. Jakarta: Bumi Aksara.

Ratminingsih, N. M. (2019). Pengajaran, Karakter, dan Cinta. Singaraja. Mahima Institute Indonesia. Jurnal IImu Pendidikan Vol. 3 No. 2 (2020).

Samani, Muclas \& Hariyanto, (2011). Konsep dan Model Pendidikan Karakter, Bandung: PT Remaja Rosdakarya.

Sekretaris Kabinet Republik Indonesia. 2020. Dasar Hukum Penanganan COVID-19. Laman Sekretaris Kabinet Republik Indonesia. https://setkab.go.id/?s=Dasar+hukum+penanganan+covid\&lang=id. Diakses 4 Mei 2020.

Sudrajat, A. (2011). Mengapa Pendidikan Karakter. Jurnal Pendidikan Karakter, 1(1), 47-58. Suharyanto. 2020. Kumpulan Peraturan Perundangan Undangan tentang Covid 19. Jakarta. Ikatan Pustakawan Indonesia.

Suharyanto. 2020. Kumpulan Peraturan Perundangan Undangan tentang Covid 19. Jakarta. Ikatan Pustakawan Indonesia.

Tim Kerja Kementerian Dalam Negeri. 2020. Pedoman Umum Menghadapi Pandemi COVID-19 Bagi Pemerintah Daerah; Pencegahan, Pengendalian, Diagnosis dan Manajemen. Kementerian Dalam Negeri Republik Indonesia. Jakarta.

Undang-Undang No. 20 Tahun 2003, Tentang Sistem Pendidikan Nasional.

Yusuf, Munawir. (2017). "Pendidikan Karakter menuju Generasi Emas 2045" dalam INOVASI PENDIDIKAN: Bunga Rampai Kajian Pendidikan Karakter, Literasi, dan Kompetensi Pendidik dalam Menghadapi Abad 21. Tersedia secara online juga di: http://jurnal.fkip.uns.ac.id/ index.php/snip/article/viewFile/11140/7930 [diakses di Bandung, Indonesia: 2 Maret 2018].

Zainal, Aqib. (2011). Pendidikan Karakter: Membangun Perilaku Positif Anak Bangsa. Bandung: Yrama Widya. 